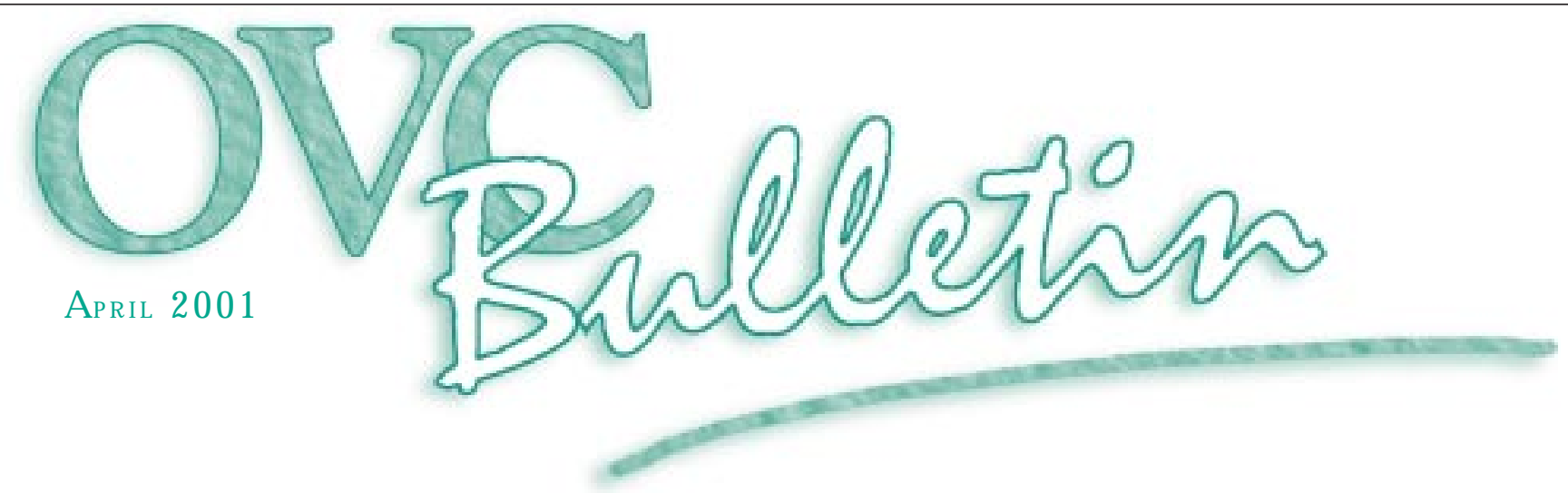

\section{UNDERSTANDING DNA EVIDENCE: A GUIDE FOR Victim Service Providers}

\author{
by Kathryn M.Turman
}

D

N A evidence is playing a larger role than ever before in criminal cases throughout the country, both to convict the guilty and exonerate the wrongly accused. Biological samples that were impossible to test for DN A 10 years ago may yield critical evidence if tested today. Because DN A evidence is a powerful tool in the search for truth, it is important that victim service providers understand the potential significance of DN A evidence in their clients' cases.

\section{What Is DNA?}

D NA, or deoxyribonucleic acid, is the fundamental building block for an individual's entire genetic makeup- our hereditary blueprint passed on to us by our parents. It is a component of virtually every cell in the human body. A person's DNA is the same in each cell and it does not change throughout a person's lifetime. For example, the DN A in a person's blood is the same as the DN A found in that person's saliva. DN A also is found in skin tissue, sweat, bone, the root and shaft of hair, earwax, mucus, urine, semen, and vaginal or rectal cells. Parts of the DN A determine our physical characteristics, such as eye and hair color, height, and bone structure, but the DN A collected from the crime scene is for evidentiary purposes only and not to determine an assailant's physical characteristics.

\section{The Value of DNA Evidence}

D $N A$ is a powerful investigative tool because, with the exception of identical twins, no two people have the same DN A. In other words, the sequence or order of the DNA building blocks is different in particular regions of the cell, making each person's DN A unique. Therefore, DN A evidence collected from a crime scene can link a suspect to a crime or eliminate one from suspicion in the same way that fingerprints are used. DN A also can identify a

\section{About This Bulletin}

Stories about the use of DNA evidence to convict offenders or exonerate defendants in criminal cases have appeared in the media with increasing frequency over the last few years. Criminal justice professionals and the public realize that forensic DNA technology is revolutionizing the way law enforcement officers investigate violent crimes, including crime scene investigation, counseling rape victims to not wash away critical evidence, accurate conviction of offenders, and connecting offenders to other brutal crimes. This bulletin seeks to strengthen crime victims' confidence in the judicial process by showing how DNA technology can empower the search for truth.

The importance of DNA evidence has grown considerably in recent years as improved technology renders more accurate results and DNA evidence is used more frequently to convict or exonerate defendants. As a result of its awesome ability to convict a perpetrator or exonerate a convicted offender, particularly in sexual assault and homicide cases, DNA evidence has become a powerful crimefighting tool. This is precisely why victim service providers need to know the significance of DNA evidence in victims' cases. They also should understand how the identification,

Continued on page 2 


\section{About This Bulletin \\ Continued from page I \\ collection, and preservation of DNA at the crime scene is critical in obtaining accurate test results. \\ Victims need to be provided with a simple but thorough explanation of how DNA testing may be used in their case, the process and procedures used, and the potential outcomes of the test results. It is important that victim serv- ice providers relay this information to victims early in the investigative process to help victims understand how DNA is used in investigating crimes and how it can improve the chances of apprehend- ing and convicting an offender.}

DNA evidence is a useful and neutral tool in the search for justice. Whether it helps convict or absolve individuals, DNA evidence will play an increasingly important role in solving crimes in the future. The result will be better justice for victims and safer communities.

victim through the DNA of relatives if a victim's body cannot be found. For example, if technicians have a biological sample from the victim, such as a bloodstain left at a crime scene, the DNA taken from that evidence can be compared with DNA from the victim's biological relatives to determine if the bloodstain belongs to the victim. When a DN A profile devel oped from evidence at one crime scene is compared with a DN A profile developed from evidence found at another crime scene, they can be linked to each other or to the same perpetrator, whether the crime was committed locally or in another state.

DN A evidence in the form of saliva, blood, skin tissue, hair, and semen are often recovered from crime scenes and can be crucial to the investigation of sexual assaults and other violent crimes. For example, during a sexual assault, biological evidence such as hair, skin tissue, semen, blood, or saliva can be left on the victim's body or at the crime scene. In addition, hair and fiber from clothing, carpet, bedding, or furniture could be transferred to the victim's body during an assault. This evidence is hel pful in proving that there was physical contact between an assailant and a victim. DN A properly collected from the victim, crime scene, or suspect can be compared with known samples to place the suspect at the scene of the crime. If there is no suspect, however, a DN A profile of the crime scene can be entered into the Federal Bureau of Investigation's (FBI) Combined DN A Index System (CODIS), which allows agencies to match DNA profiles with other profiles entered into local, state, and national databases to identify a suspect or link serial crimes.

A s with fingerprints, the effective use of DN A as evidence may require the collection and analysis of elimination samples to determine whether biological evidence came from a suspect or someone else. W hen investigating sexual assault or rape cases, it may be necessary to obtain an elimination sample, such as a blood or saliva sample, from the victim's relatives or consensual sex partner to account for all of the DNA found on the victim or at the crime scene.

\section{Evidence Collection and Preservation}

A Ithough this bulletin is not intended as an instructional manual for DN A evidence collection, every victim service provider should be aware of important issues involved in the identification, collection, transportation, and storage of DNA evidence. These issues are as important for the victim service provider as they are for the crime scene technician, nurse examiner, or other medical personnel. If DNA evidence is not initially identified, it may not be collected, and if DNA evidence is not properly collected, it may become contaminated or degraded. If properly preserved, however, DN A from body fluid stains or bones can be tested after many years in older cases in which questions of identity remain unresolved or disputed. In many cases, these substances can be analyzed to reliably link criminals to crimes or clear them as suspects.

It is crucial that victims of sexual assault understand why they should not change clothes, shower, or wash any part of their body after the assault. Semen may be found on clothing, bedding, or in the victim's vaginal, rectal, or oral regions. Saliva, which contains valuable DNA , can be found on an area where the victim was licked or bitten. In addition, if the victim scratched the assailant, skin tissue that contains the assailant's DN A can be collected from beneath the victim's fingernails.

A Ithough evidence technicians may be able to collect fingerprints and other valuable forensic evidence from the crime scene, evidence that may be inside or on a victim's body should only be collected by a physician or sexual assault nurse examiner. A medical examination ideally should be conducted within hours of the assault to treat injuries, test for sexually transmitted diseases, and collect forensic evidence. The doctor or nurse examiner will use a special kit that contains sterile cotton swabs to collect fluids from the vaginal cavity, mouth, or other parts of the victim's body that may have come in contact with the assailant. Fingernail scrapings and hair also may be collected as forensic evidence at this time. The victim's clothes, especially undergarments, that were worn during and/or after the 
assault should be collected for evidentiary purposes. In addition, the examiner will take a control standard from the victim in the form of blood or saliva and may collect a sample of the victim's head and pubic hair. Given the sensitive nature of DNA evidence, victim service providers should contact their crime laboratory personnel or evidence technicians when collection questions arise.

\section{Contamination Issues}

$B$ ecause extremely small amounts of DN A can be used as evidence, greater attention to contamination issues is necessary when identifying, collecting, and preserving DN A evidence. DNA evidence can become contaminated when DN A from another source gets mixed with DNA relevant to the case. This can happen if someone sneezes or coughs over the evidence, or if the person collecting the evidence touches his/her mouth, nose, hair, or any other part of his/her body, and then touches the area that may contain the DNA to be tested. In addition, environmental factors, such as heat and humidity, can accelerate the degradation of DNA. Degradation refers to the breaking down of DN A into smaller fragments by chemical or physical means. For example, wet or moist evidence that is packaged in plastic will provide a growth environment for bacteria, which can destroy DNA evidence. Biological evidence should al ways be thoroughly air-dried, packaged in paper, and properly labeled, ensuring that the chain of custody - a process used to document the chronological history of the evidence- is maintained. DN A evidence that is properly identified, collected, and preserved can be stored for years without risk of extensive degradation, even at room temperature.

\section{Forensic DNA Testing}

A nalyzing DN A evidence in a criminal case can take weeks or months to complete and can be expensive, especially if multiple pieces of evidence are submitted. During a criminal investigation, the police department or the prosecutor's office often pays for the analysis. In criminal DN A cases, laboratory personnel should work with the police department and prosecutor to decide which evidence may be most probative to the case. 0 nce a decision is made about what evidence should be tested, the laboratory will extract and analyze the DNA .

The laboratory analysis of DNA involves the examination of a DNA strand at 13 specific locations (loci). The DN A profile from biological evidence collected from a crime scene can be compared with a profile from a known source ( for example, a semen stain from a crime scene could be compared with a blood or saliva sample from a suspect). The DN A profiles from the biological evidence are compared with the profile from a suspect at the loci tested. If the profiles are the same, a statistic is generated which reflects how often one would expect to find this particular DN A profile in the general population. This helps in the analysis to determine whether the evidence likely came from the suspect or not. In addition, this process can seek the source of DN A evidence found at a crime scene by comparing the profile to convicted offenders in the CODIS database in situations where investigators may not yet have a suspect.

\section{DNA Testing Methods}

T hree methods are currently used to analyze DN A evidence. W hile these methods are very reliable, sometimes results cannot be obtained or are inconclusive if the quantity of the evidence is insufficient to analyze or if the evidence has been contaminated or improperly preserved. The technology used in analyzing DN A evidence is increasing in sophistication and in its ability to distinguish individuals, so it may be possible to test evidence in the future in ways that are not possible today.

The most common form of DNA analysis is called polymerase chain reaction (PCR). The development of PCR testing has greatly advanced the field of forensic DN A testing by increasing the success rate of the analysis of old, degraded, or very small biological evidentiary samples. PC R testing has allowed investigators to analyze evidence samples that previously could not be tested because the quality or the amount of starting material was insufficient for previous DN A analysis techniques.

The PCR process works by taking very small amounts of DNA from biological evidence and making millions of copies of it. This process, often referred to as PCR amplification, creates enough DNA to allow a laboratory analyst to generate a DN A profile. The process also allows laboratory technicians to analyze degraded biological material. A group of 13 different locations is used for the analysis of evidentiary samples and to generate DN A profiles from convicted offenders for the CODIS database.

Because of the capability of PC R testing to amplify very small quantities of DNA, 
extreme care must be exercised to prevent contamination when identifying, collecting, and preserving biological evidence. For this reason, investigators and laboratory personnel should always wear disposable gloves, use clean instruments, and avoid touching other objects when handling the evidence.

The other two methods used to analyze DNA evidence are restriction fragment length polymorphism (RFLP) testing and $P C R$ testing on DNA from the mitochondria of the cell. RFLP testing usually requires a sample that has 100,000 or more cells (such as a dime-sized bloodstain) and contains DN A that is not degraded or broken into smaller fragments. RFLP has been widely used since the late 1980 s and is able to exclude wrongly accused individuals. PCR testing on DN A from the mitochondria of the cell is conducted on samples that are unsuitable for RFLP or PCR nuclear DN A testing (such as dried bones or teeth, hair shafts, or samples that contain very little or highly degraded nuclear DN A ). M itochondrial DNA testing is available only in a limited number of laboratories primarily because of the time it takes to perform the tests.

\section{Interpreting Results of DNA Analysis}

T hree types of results can occur in DN A testing: inclusion, exclusion, and inconclusive results. It is important that victim service providers, investigators, and prosecutors understand the meaning of these terms and be able to explain their implications. W hile conclusive results are very reliable, DN A findings can sometimes yield results that are difficult to interpret.

\section{Inclusion}

When the DNA profile of a known individual (a victim or suspect) matches the DN A profile from the crime scene evidence, the individual is "included" as a potential source of that evidence. H owever, the strength of this inclusion depends, in part, on the number of DN A locations examined (up to 13 locations can be examined) and the statistic reflecting how often the particular profile would be found in the general population. A DNA profile shown to occur rarely in the population (for example, 1 time in 5 million people) would more strongly suggest that the individual is the source of the biological evidence than would a more common DNA profile (for example, 1 time in 5,000 people). Increasing the number of DNA locations tested typically results in more powerful statistics. For this reason, several DN A locations are tested whenever possible.

In some cases, a DN A inclusion may provide information that is of limited value to the investigative process. For example, results from samples taken from the victim may be consistent with the DNA of the victim, such as vaginal evidence in sexual assault cases. In addition, if the suspect wore a condom during the assault, was aspermatic due to a vasectomy, or did not ejaculate after the assault, additional DNA profiles may not be obtained from the evidence. The results do not mean the suspect was not present and did not commit the crime- only that the substance tested did not come from the suspect. A dditionally, inclusion does not necessarily mean a suspect is guilty.

\section{Exclusion}

When the DNA profile from an individual (a victim or suspect) does not match the DNA profile generated from the crime scene evidence, the referenced individual is "excluded" as the donor of the evidence. In some cases, it may be necessary to perform additional testing to establish the source of the DN A profile in the evidence. For example, a blood sample may be requested from the husband of a sexual assault victim to determine whether the DNA profile obtained from the vaginal swab is the result of a prior consensual act and not the assault. Exclusion does not necessarily mean a suspect is innocent.

\section{Inconclusive Results}

Inconclusive results indicate that DN A testing did not produce information that would allow an individual to be either included or excluded as the source of the biological evidence. Inconclusive results can occur for many reasons. For example, even with sensitive PCR testing, the quality or quantity of DNA obtained from the biological evidence may be insufficient to produce definitive DN A typing results. Inconclusive results also can occur if the evidentiary sample contains a mixture of DNA from several individuals (for example, a sample taken from a victim of a gang rape). Even if the suspect's DNA profile is found in the biological evidence, the presence of DNA from other sources may prohibit the establishment of an inclusive or exclusive result. If there is more than one perpetrator or if in a sexual assault case the victim recently had consensual intercourse in which semen also may have been deposited in the victim's vaginal region, the results could contain profiles from more than one person. W hen this happens, it is often not possible to determine which specific types came from which donor. The suspect cannot be excluded as a possible donor of the DNA found in the evidence sample, but a more conclusive result may not be possible. These cases must be reported as inconclusive. A s with 
all DNA results, inconclusive findings should be interpreted in the context of the other evidence in a case.

\section{DNA Evidence: Closed Cases and Unsolved Cases}

A Ithough DNA technology can be used in criminal cases to place a suspect at the scene of a crime, it also can be used to solve cases where no suspect previously existed. In addition, it can be used to reevaluate prior convictions to determine innocence. $U$ sing new technology to analyze DNA evidence in old cases can provide answers to questions of guilt or innocence and remove lingering doubts. $M$ any postconviction DNA cases have released wrongly convicted individuals based on evidence that was unsuitable for early DN A testing. The development of advanced technology, such as PCR testing, makes it possible to obtain conclusive results in cases in which previous testing might have been inconclusive. It is important to realize that while the testing or retesting may exonerate the individual, exclusionary results may not prove actual innocence. Prosecutors, defense counsel, the court, and law enforcement should concur on the need for testing on a case-by-case basis.

\section{Using CODIS To Solve Crimes}

$T$ he real investigative power of DN A technology can be realized in its application to cases where a suspect has not yet been identified. DN A technology and the FBI's CODIS database can help law enforcement identify perpetrators or link serial crimes. CODIS uses two indices to generate investigative leads in crimes that contain biological evidence- the forensic index contains DN A profiles from biological evidence left at crime scenes, and the offender index contains DNA profiles of individuals convicted of violent crimes. Each state has a DNA database law that defines which convicted offenders must enter their profiles into the database. Some states have expanded their laws to require that all felons enter their DNA profiles into the state's database. The CODIS database enables local, state, and federal forensic crime laboratories to work together to solve crimes between jurisdictions or across state lines. W hile CODIS is operated on the state level, the FBI's national database (also known as the $N$ ational DNA Index System or N DIS) may link profiles from the databases of each of the 50 states to provide law enforcement with a national network to investigate violent crime. The CODIS database will continue to have an impact on the identification of serial rapists and murderers who have committed crimes in more than one jurisdiction. It is important to realize that although the power of the CODIS database primarily is used in identifying perpetrators of crime, it also can affirm a suspect's innocence.

\section{Case Studies: The Power of a DNA Match}

\footnotetext{
othing illustrates the power of DNA evidence more effectively than the case studies- or real-life experiences - of those whose lives have been changed by such evidence. W hereas some case studies demonstrate DN A's ability to exonerate inmates wrongfully convicted of crimes, others show the powerful sense of closure and relief that
}

a DNA match can bring to victims of violent crime. The three very different case studies presented bel ow reflect the power of a DNA match and reveal some of the complexities involved in the criminal justice system. Given the pain suffered and the time irrevocably lost, these individuals' stories also indicate an urgent need to improve the capabilities and response times of DN A databases and eliminate the growing backlog of rape kits.

\section{A Lifetime Struggle: The Courage of Kellie Greene}

Kellie G reene's life changed forever late one January evening more than 7 years ago following a visit to the laundry room in her apartment complex. A s she opened the door to her apartment, she was brutally attacked by an intruder who smashed a tea kettle over her head and then raped her. A t some point during the vicious attack, which lasted 45 minutes, Kellie's rapist used dishwashing detergent. It is unknown whether the rapist used it as a lubricant, after ejaculation to cleanse himself, or purposely to destroy crucial DN A evidence that ultimately could convict him of the assault. In any case, forensic experts with the Florida Department of Law Enforcement were able to retrieve a sample of the rapist's semen from the sweater Kellie wore that night. It was this key DNA evidence that, on February 28, 1997, linked David W illiam Shaw to Kellie's attack on January 18, 1994. M ore than a month would pass, however, before she was told of the DN A match in A pril 1997.

The road to recovery for Kellie, and countless other rape survivors, is paved with anger, loss, rage, sadness, numbness, confusion, shame, guilt, fear, despair, and courage. The rape is a memory that never disappears and one that marks a woman's life forever. The experience shapes how she reacts to life's challenges and 
unexpected turns, how she gets through each day, how she sleeps at night, how she feels about her sexuality, how she feels about her body, and how she feels about men. "I think I al ways will struggle with the sexuality. It's never the same. Something that should be natural becomes something that you have to work at," Kellie said.

A fter Kellie's brutal attack and rape, she did not hesitate to report it to the authorities. "There wasn't any question. I was beat up really badly," she said. But once at the hospital, Kellie had to wait 3 hours in a hospital bed with her head wound still bleeding because the hospital would not treat her without first being seen by a medical examiner. It took seven staples to close the gash in her head.

A the time of her rape, Florida was not processing nonsuspect cases because of funding issues, and, as a result, DNA evidence in her case sat on a shelf for more than 3 years before it was analyzed. If it had not been for persistent law enforcement officers, particularly one detective, Kellie's rape kit might still be sitting on a shelf. Because officers thought Kellie's rape was similar to rapes occurring in Daytona Beach, less than 2 hours north of O rlando where Kellie's attack occurred, her rape kit was dusted off and examined. Once the results were entered into Florida's local DN A database, a hit was made via the FBI's CODIS system, allowing for an al most immediate match. $\mathrm{Her}$ rapist's DN A profile did not match the profile of the rapist in Daytona Beach but that of a man al ready serving a 25 -year sentence for beating and raping a woman 6 weeks before attacking Kellie.

W hile Kellie's rapist remains behind bars today, she continues to fight to keep him there. Q uirks in the criminal justice system, insensitivity toward the victim, and human error allowed her case to slip through the cracks more than once, resulting in a significantly reduced sentence for the offender. $\mathrm{N}$ ot until late A pril 2000 was Kellie informed of a plea agreement stating that Shaw could serve concurrentIy a 22-year sentence for Kell lie's rape, a 15-year sentence for a robbery, a 5-year sentence for obstructing justice, and the 25 -year sentence for the first rape. A motion filed by the defense attorney to clarify the sentence never reached the state's attorney's office. Finally, the judge signed orders denying Kellie restitution and denying her request that Shaw be treated with chemical castration shots. A sa result, Kellie's rapist could be released from jail as early as 2001. H ad consecutive sentences been ordered for his brutal crimes, he would not be released until 2041.

A fter her trial, Kellie drafted and introduced a bill in the Florida legislature that would mandate consecutive sentences for convicted sex offenders and murderers in prison who are found guilty of subsequent offenses. Sponsored by Representative $R$ andy Johnson ( $R$ ), the legislation was called the Sexual Predator Prosecution A ct of 2000. The bill passed Florida's $\mathrm{H}$ ouse and Senate unanimously and was signed into law in June 2000.

Kellie has been speaking out about her rape and recovery for more than 6 years. In 0 ctober 1999, she formed a nonprofit organization named SOA R - Speaking $O$ ut $A$ bout Rape, Inc. She travels across the country giving rape awareness seminars about the healing process and the importance of DN A evidence in solving cases. SO A R gave her recovery a purpose. "I was able to learn something from it and to help others. So often people think of the rape only and not the aftereffects," she pointed out. "DN A is really an amazing tool. You don't know where you're going to get the DN A from but you can get it from a lot of places."

Note: If you would like to contact Kellie $G$ reene or find out more about SOA R, call 407-836-9692, fax 407-836-9690, or visit SOA R's W eb site at www.soar99.org.

\section{A First Step Toward Healing: Crime Victim Debbie Smith's Story}

Everything changed for rape victim Debbie Smith when the man who had raped her 6 years earlier was identified. When processed through Virginia's DNA databank, the DNA sample of her assailant collected years earlier had produced a match or "hit" with DNA of an inmate in a Virginia prison. A s reflected by her compelling testimony before the $\mathrm{N}$ ational Institute of Justice's $\mathrm{N}$ ational Commission on the Future of DN A Evidence, that DNA match gave Debbie final proof that her assailant would not "come back" for her, as he had threatened. W hat is more important is that it allowed her to begin healing.

Debbie's ordeal began at about 1 p.m. on M ay 3, 1989, at her home in Williamsburg, Virginia. She was cleaning house, doing laundry, and baking a cake. A light rain was falling, and her husband-a police lieutenant-was upstairs sleeping after working the night shift and appearing in court that morning. A fter stepping outside briefly, Debbie came back in and, for some reason, left the door unlocked. W ithin a few minutes, a masked stranger entered Debbie's house and nearly destroyed her life. The stranger dragged Debbie to a wooded area. H e blindfolded her. He robbed her. A nd he raped her repeatedly, telling her, "R emember, I know where you live and I will come back if you tell anyone." 
W hen allowed to return home, Debbie told her husband about the attack but in fear begged him not to call the police. She just wanted to take a shower and wash away the pain. Debbie's husband, however, convinced her to notify the police and visit a hospital where trained medical personnel could examine her and collect physical evidence that might identify the rapist. If she showered, that evidence would be lost. Debbie thanks God every day for her husband's advice. A lthough she was "plucked and scraped and swabbed" during her visit to the hospital, Debbie's rape examination kit produced the crucial DNA evidence that ultimately identified her attacker.

True peace of mind came for Debbie Smith on July 26, 1995, when a forensic scientist for the Commonwealth of Virginia notified Debbie that a DN A match had been made. $\mathrm{H}$ er assailant was serving time in a Virginia prison for a separate offense. For the first time since the rape, Debbie knew that her attacker could not come after her. Debbie learned later that her assailant had gone to jail only months after raping her. Because of a backlog in Virginia's D N A database, she waited 6 years to hear about it.

\section{Proof of Innocence: Inmate Ronald Cotton's Story}

Ronald Cotton's story begins on a summer night in 1984 when two rapes were committed in Burlington, $\mathrm{N}$ orth C arolina. In each case, an assailant entered an apartment, cut the phone wires, raped a woman at knifepoint, and stole money and other items. Both victims were taken to the hospital, where full rape examination kits were completed.

The first victim, 22-year-old Jennifer Thompson, described her attacker as a tall A frican-A merican man in his early 20s. Police collected photographs of area men meeting that description, including 22-year-old Ronald Cotton, a Burlington resident employed at a restaurant near Thompson's apartment. Cotton had two prior convictions: one for breaking and entering, and another for assault with intent to rape. Thompson selected Cotton from police photos as her rapist. W hen Cotton visited the police station to clear up the misunderstanding, he only strengthened the case mounting against him. He claimed that he had been with friends on the night of the rapes, but those friends did not corroborate his alibi. A t a physical lineup of suspects, Thompson again selected $\mathrm{C}$ otton. In A ugust 1984, police arrested Cotton and took him into custody. In January 1985 , Cotton was convicted of Thompson's rape and sentenced to life in prison. That verdict, however, was overturned, and a new trial was ordered. Cotton was optimistic given a crucial discovery he had made about one of his fellow inmates, Bobby Poole- a tall A frican-A merican young man from Burlington also convicted of rape who bore a strong resemblance to the composite sketch used in Cotton's case. Poole had reportedly bragged to inmates that he had committed the rapes for which $\mathrm{C}$ otton was serving time.

The second trial was even more devastating than the first. Both victims testified against $C$ otton; the jury did not believe that Poole was the real assailant; and, most damaging of all, the court withheld evidence of Poole's alleged confessions. Convicted of both rapes, Cotton received two life sentences plus 55 years in prison.

Back in prison, Cotton "waited it out" for years. In 1994, however, he learned about DN A testing (a procedure unavailable at the time of his trials). He filed and won a motion for DN A testing. In 1995, Burlington police turned over to the court all case evidence containing semen or other bodily fluids. Samples from Jennifer Thompson had deteriorated and could not be tested, but those from the second victim provided a breakthrough for $C$ otton. $\mathrm{O}$ a tiny vaginal swab, scientists found a bit of sperm. Subjected to PCR testing, that sample showed no match to Ronald Cotton. He could not have committed the crime.

The state DNA database matched the sample to Bobby Poole. On June 30 , 1995, al most 11 years after the rapes and $10^{1} / 2$ years after being taken into custody, Ronald Cotton was cleared of all charges and released from prison.

\section{Postconviction DNA Testing}

V ictims and surviving family members confront a number of issues and events following the conviction and sentencing of a defendant. The impact of the crime does not end with the incarceration of the offender. Convicted defendants have the right to appeal their sentences, the opportunity for parole, and the ability to file subsequent requests for additional DNA testing. All of these postconviction events are upsetting to victims and families and serve as painful reminders of the suffering and loss associated with the crime. It is extremely important that crime victims and family members are approached with great sensitivity. This is especially critical when the conviction was based primarily on eyewitness identification by the victim. Victim service providers must be aware that victims and their families may need special services to help them cope with postconviction developments.

In the context of postconviction DN A testing, it is important to realize that if a convicted offender requests DNA testing 
of old or newly discovered evidence, this does not mean the request will be granted. Postconviction requests, in which DNA evidence is available for testing and the test results are likely to exonerate an offender, should be handled with great care because it may be necessary to obtain samples from victims and third parties for the testing process. Prosecutors and victim service providers should ensure that victim counseling resources are available through their offices or a communitybased assistance program.

If testing results produce excul patory evidence, particularly in mistaken eyewitness identification cases, victims may still believe the defendant is guilty. Victims may be upset and angry. For example, the credibility of sexual assault victims is usually attacked in trial, and a conviction is viewed as a significant validation of their credibility. To face having their credibility called into question again can cause tremendous distress. In addition, some victims may feel terribly guilty about their part in convicting an innocent person. Reassure the victim that she did the best she could at the time and that memory can be fallible. It may help to remind the victim that DNA technology, which may not have been available at the time of the original investigation, is an important tool in making sure the right person is convicted. Remind the victim or survivor that the criminal justice system is not perfect, and emphasize the importance of knowing the truth and identifying the right perpetrator to ensure justice and prevent future victimization of other individuals.

A Iso, it may help to inform victims of the following:

- Even the Innocence Project, which uses DN A testing to exonerate persons who have been wrongfully convicted, concedes that in many cases in which postconviction requests are made for DN A testing, the results have confirmed the identity of the convicted person as the true perpetrator. This confirmation may have a significant impact on decisions regarding the perpetrator's probation or parole.

- The victim should be assured that everyone in the system, particularly prosecutors and judges, will make sure that ambiguous results that do not clearly exonerate the perpetrator will not weaken the conviction or result in a new trial.

- If postconviction testing of DNA evidence results in a valid exclusion, the victim can be reassured that growing DNA databases will increase the likelihood of identifying the true perpetrator. DNA databases also will make it easier to accurately identify and link perpetrators in future cases.

M eanwhile, a number of states have passed victims' rights statutes that require notification of victims, including notification of appeal proceedings, prison release, application for pardon, or commutation of sentence. A gencies involved in postconviction DN A cases should make certain they comply with applicable state statutes.

\section{Conclusion}

T he importance of the role forensic DNA evidence plays in solving sexual assault and homicide cases cannot be overstated. DN A evidence is a crucial tool used in effective police work to solve violent crimes. For those who have been wrongly accused, sentenced, and imprisoned-sometimes for many years- for a crime they did not commit,
DN A evidence exonerates the innocent and alerts law enforcement to pursue the true offender. By convicting the guilty and freeing the innocent, DN A evidence truly serves the interests of justice.

A Ithough DNA is a powerful tool, it is useless to the criminal justice system if not properly collected, preserved, and tested. M embers of the criminal justice community must be trained to identify DN A evidence, to understand its significance, and to counsel victims on how valuable it is in apprehending and convicting offenders.

A s technology to test forensic DN A evidence advances and huge backlogs of rape kits decline in laboratories nationwide, crimes will be solved more quickly and comparisons between known offenders and unsolved cases will increase using the FBI's CO DIS database.

For too long, victims of violent crime have been ignored, but the criminal justice community now has an amazing tool that will offer victims relief, peace of mind, and some closure for having experienced and survived brutal sexual crimes or the death of a loved one. Victim service providers, law enforcement, evidence technicians, prosecutors, and others involved in bringing justice to crime victims are at the forefront of the DNA revolution, and they must strive to educate the public about the vital role DN A plays in protecting victims from further trauma.

\section{Glossary}

T his glossary highlights some of the technological terms victim service providers may encounter when dealing with victims during a criminal investigation. $M$ any terms have been used in this bulletin, but others are listed to give 
providers a more thorough understanding of the importance of DNA.

ABO Blood Typing: A commonly used genetic typing test that uses antibodies to detect variations on the surface of human red blood cells. Individuals are typed as having an $A, B, O$, or A B blood type by testing liquid or stains from body fluids (such as blood, saliva, vaginal secretions). $O$ ne out of every three randomly selected pairs of people have the same A BO blood type.

Amelogenin: A gene present on the $X$ and $Y$ sex chromosomes that is used in DNA identification testing to determine the gender of the donor of the DNA of a biological sample.

Biological Evidence: Evidence commonly recovered from crime scenes in the form of hair, tissue, bones, teeth, blood, or other bodily fluids.

Chain of Custody: A record of individuals who have had physical possession of the evidence and the process used to maintain and document the chronological history of the evidence. D ocuments should include the name or initials of the individual collecting the evidence, each person or entity subsequently having custody of it, the dates the items were collected or transferred, where the items were collected, the agency and case number, the victim's or suspect's name (if known), and a brief description of the item.

CODIS: The Combined DN A Index System is an electronic database of DN A profiles obtained from evidence samples from unsolved crimes and from known individuals convicted of particular crimes. Contributions to this database are made through state crime laboratories and the data are maintained by the $\mathrm{FBI}$.
Contamination: The undesirable transfer of material to physical evidence (DNA) from another source.

Degradation: The breaking down of DNA into smaller fragments by chemical or physical processes. Degradation of DNA may limit its use as evidence.

DNA: Deoxyribonucleic acid, often referred to as the "blueprint of life," is an organic substance found in nearly all cells. DN A determines each person's individual characteristics. A $n$ individual's DNA is unique except in identical twins. DNA in the cell nucleus is the genetic material inherited from our biological parents. The shape of DNA resembles a rope ladder that has been twisted (double helix).

DNA Advisory Board (DAB): C reated under the DNA Identification A ct of 1994, DA B established standards for forensic DN A testing laboratories and held its last meeting in fall 2000.

DNA Marker: A piece of DNA from a known location in the DNA molecule, which differs between people. The DN A marker is used to identify the specific genetic variations an individual possesses.

DNA Profile: A set of genetic characteristics that results from forensic DN A analysis of several DN A markers.

DNA Typing or Profiling: The process of testing to identify DNA patterns or types. In the forensic setting, this testing is used to indicate parentage or to exclude or include individuals as possible sources of body fluid stains (blood, saliva, or semen) and other biological evidence (bones, teeth, or hair).

Elimination or Reference Sample: A term used to describe a sample of known source taken for comparison purposes. A $n$ elimination sample is one of known source taken from a person who had lawful access to the crime scene to be used for comparison with evidence of the same type. Examples of elimination samples include blood or cheek (buccal) swabs for DNA analysis, fingerprints from occupants, tire tread impressions from police vehicles, or footwear impressions from emergency medical personnel. A reference sample is material of a verifiable/ documented source which shows an association or link between an offender, crime scene, and/or victim when compared with evidence of an unknown source. For example, a carpet cutting taken from a location suspected as the point of transfer for comparison with the fibers recovered from a suspect's shoes, a sample of paint removed from a suspect's vehicle to be compared with paint found on a victim's vehicle following an accident, or a sample of the suspect's and/or victim's blood submitted for comparison with a bloodstained shirt recovered as evidence.

Exclusion: A DNA test result indicating that an individual is excluded as the source of DNA evidence. In the context of a criminal case, exclusion does not necessarily mean a suspect is innocent.

Exemplar: A biological sample (such as blood or saliva) collected from a known individual to be used for comparison to DN A test results from evidence samples. A Iso referred to as a standard.

Inclusion: A DNA test result indicating that an individual is not excluded as the source of DNA evidence. In the context of a criminal case, inclusion does not necessarily mean a suspect is guilty.

Inconclusive Results: A situation in which no conclusion can be reached regarding testing done due to one of many possible reasons ( such as no results 
obtained, uninterpretable results obtained, no exemplar/standard available for testing).

Locus (pl. loci): The specific physical location of a gene on a chromosome.

Mitochondrial DNA: DNA found in the mitochondria in each cell of a body. The sequencing of mitochondrial DN A can link individuals descended from a common female ancestor.

Nuclear DNA: DNA found in the nucleus of a cell. DN A testing using RFLP, DQA 1 (DQ a), PM , D 1S80, or ST Rs screen markers in nuclear DNA .

PCR: Polymerase chain reaction is a process used in DN A identification testing in which one or more specific small regions of the DNA are copied using a DN A polymerase enzyme so that a sufficient amount of DN A is generated for analysis. This process enables scientists to obtain genetic information from small or degraded specimens.

Polymorphism: Variations in DNA sequences in a population that are detected in human DNA identification testing.

Reference Sample: See Elimination or Reference Sample listing.

RFLP: Restriction fragment length polymorphism is a process used in DNA identification testing in which size (fragment length) differences at specific regions of the DNA are detected.

STR: Short tandem repeat(s) are small regions of the DNA that contain short segments (usually 2, 3, 4, or 5 bases long) repeated several times in tandem (sideby-side). Thirteen ST R sequences have been selected as the genetic markers to be used in CODIS.
Substrates: A ny background material upon which a biological sample has been deposited (e.g., clothing, glass, wood, or upholstery).

\section{References}

Connors, E., T. Lundregan, N. M iller, and T. M cEwen. 1996. Convicted by Juries, Exonerated by Science: Case Studies in the Use of DNA Evidence To Establish Innocence After Trial. W ashington, DC: U .S. Department of Justice, $\mathrm{N}$ ational Institute of Justice.

H ammond, H .A ., and C. Thomas C askey. 1997. Automated DNA Typing: Method of the Future? Washington, DC: U.S. Department of Justice, $\mathrm{N}$ ational Institute of Justice.

Handbook of Forensic Services: Evidence Examinations-DNA General. 1999. W ashington, DC: Federal Bureau of Investigation.

Inman, K., and N. Rudin. 1997. An Introduction to Forensic DNA Analysis. Boca Raton, FL: C RC Press, Inc.

Ledray, L.E. 2000. Sexual Assault Nurse Examiner (S.A.N.E.) Development and Operation Guide. Washington, DC: U.S. D epartment of Justice, O ffice for Victims of Crime.

$\mathrm{N}$ ational $\mathrm{C}$ ommission on the Future of DN A Evidence. 1999. Postconviction DNA Testing: Recommendations for Handling Requests. W ashington, DC: U .S. D epartment of Justice, $\mathrm{N}$ ational Institute of Justice.

$\mathrm{N}$ ational Commission on the Future of DN A Evidence. 1999. What Every Law Enforcement Officer Should Know About DNA Evidence. Washington, DC: U S. Department of Justice, $\mathrm{N}$ ational Institute of Justice.
N ational Research C ouncil. 1992. DNA Technology in Forensic Science. Washington, DC: N ational A cademy Press.

N ational Research C ouncil. 1996. The Evaluation of Forensic DNA Evidence. Washington, DC: $N$ ational A cademy Press.

Weedn, V.W., and J.W. Hicks. 1998. The Unrealized Potential of DNA Testing. Washington, DC: U.S. Department of Justice, $N$ ational Institute of Justice.

\section{For Further Information}

American Prosecutors Research Institute

99 C anal C enter Plaza, Suite 510

A lexandria, VA 22314

703-549-4253

W orld Wide W eb:

www.ndaa-apri.org/apri//ndex.html

Federal Bureau of Investigation (FBI) 202-324-3000

W orld W ide W eb: www.fbi.gov

National Center for Victims of Crime (NCVC)

2111 W ilson Boulevard, Suite 300

A rlington, VA 22201

703-276-2880

Emergency: 1-800-394-2255

E-mail: ncvc@ncvc.org

W orld W ide W eb: www.ncvc.org

National Commission on the Future of DNA Evidence

$N$ ational Institute of J ustice

810 Seventh Street N W.

Seventh Floor

Washington, DC 20531

202-307-2942

W orld W ide W eb: www.ojp.usdoj.gov/nij/dna 
National Criminal Justice Reference

Service (NCJRS)

P.O. Box 6000

Rockville, M D 20849-6000

$1-800-851-3420$ or $301-519-5500$

TTY: 1-877-712-9279 (toll free)

or 301-947-8374 (local)

Office for Victims of Crime (OVC)

U.S. Department of Justice

810 Seventh Street N W.

Eighth Floor

W ashington, DC 20531

202-307-5983

Fax: 202-514-6383

W orld W ide W eb: www.ojp.usdoj.gov/ove

Office for Victims of Crime Resource

Center (OVCRC)

P.O. Box 6000

Rockville, M D 20849-6000

1-800-627-6872

TTY: 1-877-712-9279 (toll free)

W orld W ide W eb: www.ncjrs.org

Rape, Abuse \& Incest National

Network (RAINN)

635-B Pennsylvania A venue SE.

W ashington, DC 20003

202-544-1034

$\mathrm{N}$ ational $\mathrm{H}$ otline: 1-800-656- $\mathrm{O} \mathrm{OPE}$

Fax: 202-544-3556

E-mail: rainnmail@aol.com

W orld W ide W eb: www.rainn.org

Sexual Assault Nurse Examiner

(S.A.N.E.)-Sexual Assault Response

Team (S.A.R.T.)

W orld W ide W eb: www.sane-sart.com

This W eb site, sponsored by the Sexual

A ssault Resource Service (SA RS) of
Minneapolis, M innesota, provides information and technical assistance to individuals and institutions interested in developing new S.A .N .E.-S.A .R.T. programs or improving existing ones. SA RS established the Sexual Assault Nurse Examiner Development and Operation Guide, which offers users a multidisciplinary, victim-centered way of responding to sexual assault victims.

Speaking Out About Rape, Inc. (SOAR)

69 East Pine Street

O rlando, FL 32801

407-836-9692

Fax: 407-836-9690

W orld Wide Web: www.soar99.org

Violence Against Women Office

(VAWO)

U S. D epartment of Justice

810 Seventh Street N W.

W ashington, DC 20531

202-307-6026

Fax: 202-305-2589

W orld W ide W eb:

www.ojp.usdoj.gov/vawo

The V iolence A gainst W omen Office (VAW O) was created in 1995 to implement the 1994 Violence $A$ gainst W omen A ct (VAWA) and to lead the national effort to stop domestic violence, sexual assault, and stalking of women. VAW 0 works with victim advocates and law enforcement to devel op grant programs that support a variety of services for women, including advocacy, emergency shelter, law enforcement protection, and legal aid. Two critical VAW 0 grants are the
ST O P (Services*Training* O fficers* Prosecutors) Violence A gainst W omen Formula $G$ rants and the ST O P Violence A gainst Indian Women Discretionary $G$ rants.

The STOP (Services*Training* Officers*Prosecutors) Violence Against Women Formula Grants are awarded to the states, District of Columbia, and territories to develop and strengthen their criminal justice system's response to violence against women and to support and enhance services for victims. Each grantee must allocate at least 25 percent of the grant funds to law enforcement, at least 25 percent to prosecution, at least 30 percent to victim services, and at least 5 percent to courts. The remaining 15 percent can be allocated at each grantee's discretion within the broad parameters established by VAWA .

The STOP Violence Against Indian Women Discretionary Grants are awarded to develop and strengthen tribal law enforcement and prosecution efforts to combat violence against native women and develop and enhance services for victims. Tribes that have law enforcement and prosecution responsibilities must allocate at least 25 percent of their grant funds to tribal law enforcement, at least 25 percent to tribal prosecution, at least 30 percent to victim services, and at least 5 percent to courts. The remaining 15 percent can be allocated at each grantee's discretion within the broad parameters established by VAWA. 


\section{Acknowledgments}

Kathryn M cKay Turman joined the O ffice for Victims of C rime in July 1998. She served as 1 of 22 Commissioners appointed to the $\mathrm{N}$ ational Commission on the Future of DNA Evidence. From 1994 to 1998, she was C hief of the Victim W itness A ssistance U nit in the U .S. A ttorney's O ffice for the District of Columbia. A s head of that unit, she oversaw services to about 10,000 victims a year, ranging from victims of misdemeanor crimes to international terrorism. From 1991 to 1993, she served as Director of the Justice Department's M issing and Exploited C hildren's Program. Prior to joining the U.S. Department of Justice in 1991, she was Special A ssistant to the late U .S. Senator John H einz. She is a social worker and a graduate of the $U$ niversity of Texas at $A$ ustin. She gives special thanks and recognition to C hris A splen and Dr. Lisa Forman, both of the $\mathrm{N}$ ational Commission on the Future of DN A Evidence, lead writer/editor Theodosia $\mathrm{C}$ raig, and contributing writer/editor $\mathrm{N}$ ancy $\mathrm{W}$ al sh.
Preparation of this document was supported by the Office for Victims of Crime, Office of Justice Programs, U.S. Department of Justice. The opinions, findings, conclusions, and recommendations expressed in this document are those of the author and do not necessarily represent the official position or policies of the U.S. Department of Justice.

The Office for Victims of Crime is a component of the Office of Justice Programs, which also includes the Bureau of Justice Assistance, the Bureau of Justice Statistics, the National Institute of Justice, and the Office of Juvenile Justice and Delinquency Prevention.

\section{U.S. Department of Justice}

Office of Justice Programs

Office for Victims of Crime

Washington, DC 20531

Official Business

Penalty for Private Use $\$ 300$
PRESORTED STANDARD POSTAGE \& FEES PAID DOJ/OVC PERMIT NO. G-91 